\title{
Mechanisms, Problems, and Strategies of Teachers in Implementing Curriculum Reform: A Case Study of Indonesian at Elementary Schools
}

\author{
Sudirman $^{1}$, Abd. Haling ${ }^{2}$ \\ ${ }^{12}$ State University of Makassar, Indonesia
}

\begin{abstract}
This study aims to describe the mechanisms, problems, and strategies in implementing curriculum reform (CR) in Indonesian at elementary schools. This study used a qualitative approach in the form of cases in a Superior Elementary School (SES) and a Regular Elementary School (RES). Subject of study consist of two teachers, a teacher at the SES and also at the RES one. Result showed that (1) implementation of curriculum mechanism are motivate, organize, introduce, explain, explore, clarify and reflect, (2) the problems arose which were teachers lack confidence in completing the syllabus, the teachers' experiences obstacles in developing basic competencies operationally, textbooks content is less in accordance with the curriculum, teachers have not mastered the subject and lack understanding about assessment applied, (3) the teacher's strategies are, both teachers have a high motivation and expectation to achieving the goal optimally, adjust the curriculum by developing competency with concrete examples, taking part in Teacher's Working Group, and making communicate to the instructor directly. Study also showed that at the SES's students had higher enthusiasm then at the RES's students in the teaching and learning process of Indonesian. Yet, curriculum's message has not been fully delivered as we expected. So, training is needed on syllabus development, basic competency development, mastery of material and presentation techniques and assessment of lessons in the curriculum reform especially in RES.
\end{abstract}

Keywords - implementation, curriculum, strategy, innovative, adaptation

\section{Introduction}

A curriculum reform arises variant impacts in its implementing. Teacher is a main person in implementing.[1] [2] [3]. To implementing the curriculum reform, teachers will have challenged to design and implement teaching and learning strategies and innovative methods. Something that is very possible that the implementation of curriculum design preparation so great, but not much benefit when the process of implementation was not effective [4]. Implementation is important because it is a tool for achieve the objective [1] [5].

A strong indicator of the need for discussion is, 56 percent of students could solve the problems in writing with the perfect reading. The average outcome of the race of Indonesian in 
the district of Bone elementary school in 2008, just reaching 58 percent. Income is in line with studies of Sudirman (2011) that the majority of elementary school students are at a weak level of proficiency in writing or composing. This weakness is also encountered by Che Zanariah \& Fadzilah [6] that students did not understand the material stimuli, they copy only during exercise or exams and would not understand the question in essay writing.

\section{Methods}

Uses Illuminative Assessment Model Parlett \& Hamilton [7]. A case study of comparison between superior elementary schools (SES) and regular elementary schools (RES) in Bone. Study of subjects by purposive sampling is a fifth-grade teacher at the SES or (first teacher/T-1) and in the RES or (second teacher/T-2). The data collected by in-depth interviews, observation, recording and analyzing of documents. The data were analyzed qualitatively narrative [8] [9] [10]. According to Bungin [8], that qualitative data analysis was carried out in conjunction with data collection activities. The researcher's ability in sensing, feeling, experience, and intelligence fully involved for disaggregating to build categories. The researcher commended in the field notes and interview notes to identify possible themes, interpretations, and questions. The researcher's comment always separated from the actual data, typically by being enclosed in parentheses [10]. Based on those data, first, the researcher interpreted by building categories. The data were not relevant to the research question was left out, and then re-typing it for transcription formation. Second, involved the introduction of data. In this phase, the researcher read the data as closely and repeatedly as possible to determine the appropriate category. The coded verses were one unit of analysis and were given the category names as tentative definitions. Finally, the processed data forms categories based on the same features or patterns that it has. The encoding process that has been implemented helps the researcher created the data grouping. Codes were based on emerging concepts and themes, facilitating the process of identifying, selecting, and grouping data.

To this end, the researcher was re-reading the data over and over again transcription / verbatim teaching to identify sentences that could describe a category. The researcher continued reading to find similar verses in the category made in the second phase. Whereas a sentence that does not fit into the existing category, a new category was created. The categories that were formed are named after words derived from the data of the researcher's own ideas and related to the study of the library. All those categories, themes, and descriptions were restated in the form of narratives or qualitative reports [9].

\section{Result and Discussion}

This research found seven series activities of Indonesian teaching and learning, some problems in implementing curriculum reform, and some strategies of teachers to solve the problems. The SES's students had higher enthusiasm then at the RES's students in Indonesian teaching and learning process.

\subsection{Mechanism of Indonesian Teaching and Learning}

There were seven mechanisms in Indonesian teaching and learning in implementing a curriculum reform as follows: 


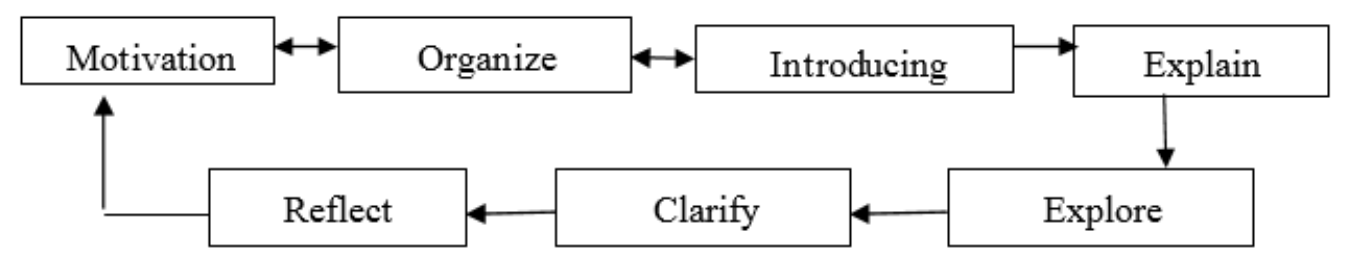

Chart 1. Mechanism of Indonesian teaching and learning process in elementary school

According to above chat, T-1 began the learning and teaching with motivated students with a variety of ways such as showed a picture, made a short story and promoting the quiz. The transcript of an interviewed with T-1 as below:

"Then, I gave motivation to attract (students') attention. For example, told a stories about successful people, those who did good work, number one can be given present like... can be given gift or other." (Interviewed.T-1. 21.9.11).

The promotion of motivation and recognition organization is so affected the interest of the students for next teaching and learning process as has been stated by Hemchand [11]; Johnson [12]; Santyasa [13]. In the organizing stage, students could gain an understanding of the material that needs to be completed first, and also later. The teacher tried to make every student enjoy the lesson. Stages were very meaningful to introduce the students to get a clear general description, how the students do the tasks, the intended target and how teachers could use to assess their work as affirmation Cullingford [14]; Mok Soon Sang [2]. At the core stages, both teachers promoted enlightenment, exploration and clarification. At the exploration stage, the learning activities were generally carried out in groups of students. Each group got a worksheet as stated in the learning design. In exploration stage, teachers and students discuss the lesson material. Each group got the same opportunity to presenting their work and the teacher as the moderator. The teachers made clarifications in the form of classroom discussion on students' work, especially that done in groups.

At the end of the learning activity, T-1 revealed meaningful reflection materials that were considered important to reinforce students' understanding that have been described as well as suggested by Altinyelken [15]; Cullingford [14]. Both teachers took the opportunity to understand the individual student attention as the opinion Cullingford [14]; Muijs [16]. Monitoring conducted during both teachers and students explored competency material. Teacher's problems arose in this case due to Indonesian text book does not correspond to the curriculum, lack of school principal guidance, lack of direct superintendents controlled, and there was no guide book. Moreover, the syllabus content was not appropriate if they directly apply to students.

A part of interview recorded with T-1 and T-2, said:

"... I didn't understand what was the curriculum reform mean, quite frankly, what exactly prompted SBC, but not all. And sometimes in the syllabus was also unclear. (Interviewed.T1.20-07-2011).

"If...if the indicator of curriculum ......" (with a frown her forehead to remembered, but did not find anything and smile). What was it? It was very difficult for me to make indicator (Interviewed.T-2 14.9.11)

\subsection{Problems in Implementing of Indonesian Curriculum Reform}

Teachers lack confidence in completing the syllabus, the teachers' experiences obstacles in developing basic competencies operationally, textbooks content is less in accordance with the 
curriculum, teachers have not mastered the subject and lack understanding about assessment applied. Because of those problems, curriculum's message has not been fully delivered as we expected. To solve the problems, both teacher have some strategies. First, both teachers have a high motivation and expectation to achieving the goal optimally. Second, they made adjustments according to the environmental conditions at their school, such as the proposed statement by Manhong Lai [4] and Print [17]. Third, they have been taking part in Teacher's Working Group. They always connected anything that has students understood and trained anything that has been learned previously as declared by Cullingford [14] and Muijs [16]. Fourth, they communicated to the instructor directly.

Strategies of Teacher to Solve the Problems

The teachers have a high motivation and expectation to achieving the goal optimally, using repetition method, adjust the curriculum by developing competency, taking part in Teacher's Working Group, and making communicate to the instructor directly. The teachers were developing their syllabus content by considering their interests, abilities of students, availability of teaching facilities and learning resources which can be exploited.

Techniques in developing syllabus content are (1) paraphrasing the subject matter by using sentences which was easier to understand and frequently used by the student, student habits, (2) giving concrete examples or analogues which were closer to the students, and (3) using the tools and learning resources available in the student environment. The use of language in the curriculum competencies also assessed rather high. The teachers sometimes used the local language (Bugisness) to facilitate students absorbing the material. In brief, the teachers made adjustments according to the environmental conditions at their school and also at their student capacity.

\section{Conclusion}

There are seven mechanisms in implementing Indonesian curriculum reform in elementary school. Using curriculum reform arose some problems either teacher or student. To solved the problems, both teachers have a series way. They have positive attitude and have a high motivation and expectation. There were technique and style differences between T-1 and T-2. The SES's students had higher enthusiasm then at the RES's students in implementing of Indonesian curriculum reform. Curriculum's message has not been fully delivered as we expected. In doing so, training is needed on syllabus development, basic competency development, mastery of material and presentation techniques and assessment of lessons in the curriculum reform especially in RES.

\section{References}

[1] J. Kepler, Curriculum Implementation. Austria: Linz University, 2005.

[2] M. S. Sang, Falsafah Pendidikan, Kurikulum dan Profesionalisme Keguruan. Selangor: Penerbitan Multimedia SDN.BHD, 2010.

[3] W. Sanjaya, Kurikulum dan Pembelajaran. Jakarta: Kencana Prenada Media Group, 2010.

[4] M. Lai, "Teacher development under curriculum reform: a case study of a secondary school in mainland China," Int. Rev. Educ., vol. 56, 2010.

[5] S. Sukmadinata, Pengembangan Kurikulum: Teori dan Praktek. Bandung: Remaja Rosdakarya, 2010. 
[6] C. H. C. Zanariah and A. . Fadzilah, "Pelaksanaan pengajaran dan pembelajaran kemahiran manulis di sekolah rendah," J. Pendidik. Bhs. Melayu, vol. 1, no. 1, 2011.

[7] M. Parlett and G. Hamilton, Evaluation as Illumination, in Tawney,D. Curriculum Evaluation Today. Trends and Implication. Macmillan, 1972.

[8] B. Bungin, Penelitian Kualitatif. Jakarta: Kencana Prenada Media Group, 2007.

[9] J. W. Creswell, Research Design: Pendekatan Kualitatif, Kuantitatif dan Mixed. Yogyakarta: Pustaka Siswa, 2010.

[10] J. H. McMillan and S. Schumacher, Research in Education. Evidence-Based Inquiry. Boston: Pearson, 2006.

[11] T. . Hemchand, Curriculum development. In Encyclopaedia of Educational Problems. New Delhi: Crescent Publishing Corporation, 2008.

[12] J. A. Johnson, Principle of Effective Change: Curriculum Revision that Works. 2008.

[13] I. W. Santyasa, "Model pembelajaran inovatif dalam implementasi Kurikulum Berbasis Kompetensi. Kertas kerja dalam penataran guru-guru sekolah menengah se-Kabupaten Jembrana, Indonesia," 2005.

[14] C. Cullingford, The Art of Teaching: Experience of School. London: Routledge, 2010.

[15] H. K. Altinyelken, Curriculum change in Uganda: Teacher perspectives on the new thematic curriculum. International of Journal of Education Development. 2010.

[16] D. Muijs and D. Reynolds, Effective Teaching: Evidence and Practice. Londong: Paul Chapman Publishing, 2001.

[17] M. Print, Curriculum Development and Design. Australia: Allen \& Unwin Pty.Ltd, 1993. 